\title{
Soaking the Common Bean in a Domestic Preparation Reduced the Contents of Raffinose-Type Oligosaccharides but Did Not Interfere with Nutritive Value
}

\author{
Keila da Silva QueIroz, Admar Costa de OliverRA*, Elizabete HelBig, \\ Soely Maria Pissini Machado ReIS and Francisco CARRARO \\ Departamento de Planejamento Alimentar e Nutrição, Faculdade de Engenharia de Alimentos, \\ Universidade Estadual de Campinas, Caixa Postal 6121, 13083-970, Campinas, SP, Brasil
}

(Received September 7, 2001)

\begin{abstract}
Summary The objective of this study was to verify the effect of soaking on the factors causing flatulence in the common bean (Phaseolus vulgaris, L.) cv. IAC-Carioca during domestic preparation. A biological assay using recently weaned (21 days) male Wistar rats provided the Food Conversion Efficiency (FCE) and the Net Protein Ratio (NPR). Five treatments were carried out with isocaloric $(350.9 \pm 37.9 \mathrm{kcal} / 100 \mathrm{~g})$ and isoprotein $(12.0 \pm$ $0.5 \%$ ) experimental diets, with the following protein sources: beans cooked without soaking (BNS), beans soaked and cooked with the soaking water (BSWW), beans soaked and cooked without the residual soaking water (BSNW), control diet (casein) (CC), casein plus the total soluble solids found in the soaking water (CSS) for comparative purposes, and an aproteic diet (AP) for corrective purposes, all diets offered ad libitum. The contents of raffinose-type oligosaccharides were determined in the different domestic preparations of the beans. Significant reductions were observed in the contents of the oligosaccharides raffinose $(25.0 \%)$, stachyose $(24.8 \%)$, and verbascose $(41.7 \%)$, and in the contents of total sugars $(80.6 \%)$, reducing sugars $(58.2 \%)$, nonreducing sugars $(90.3 \%)$, and starch $(26.8 \%)$ when soaking took place before cooking and elimination of the soaking water not absorbed by the beans (BSNW) was used. No significant difference $(p>0.05)$ was observed between the values for FCE and NPR of the control diet (casein) and control diet plus soaking water soluble solids. Neither was any significant difference between the values for the different bean treatments found, though the values for FCE and NPR were lower than those obtained for casein treatments. Thus it was verified that although the domestic preparation of the common bean significantly reduced the contents of raffinose-type oligosaccharides, total reducing and nonreducing sugars and starch, it did not interfere with its nutritive value.
\end{abstract}

Key Words common bean, soaking, raffinose-type oligosaccharides, nutritive value

The common bean is a legume of high economic and social expression, constituting the basic food of various populations and representing the main protein/energy source for low-income classes. Brazil is the largest world producer of this legume and one of the greatest of its consumers; the bean is cultivated throughout the country (1). The common bean makes a substantial contribution to the nutritional value of cereal-based diets, being an excellent source of protein (18-40\%) and carbohydrates (38-60\%) and also supplying thiamine, niacin, calcium, and iron (2). As an energy source, the carbohydrates are mostly represented by the starch and fiber contents (3), the oligosaccharides being present in small but significant amounts.

The raffinose-type oligosaccharides are responsible for flatulence-retention of gases in the intestine-in humans, which can interfere in the use and acceptance of the common bean. Many investigations have shown that after the ingestion of beans, the raffinose-type oligosaccharides, besides causing flatulence, cause a

\footnotetext{
* Corresponding author.
}

sensation of abdominal discomfort and diarrhoea (4). In these oligosaccharides, sucrose is the basic unit and contains one or more $\alpha$-galactopiranosil groups in its structure, the $\alpha$-galactosil units always being connected to the left side of the sucrose, more specifically to the glucose molecule (5). Apparently the cause of flatulence is a lack of the enzyme $\alpha$-galactosidase (E.C. 3.2.1.22) in the human digestive tract, since the raffinose-type oligosaccharides are neither hydrolized nor absorbed in the small intestine, and on passing to the large intestine they are anaerobically fermented, producing $\mathrm{H}_{2}, \mathrm{CO}_{2}$, and $\mathrm{CH}_{4}$ gases, causing flatulence, diarrhoea, and abdominal pain (6).

The domestic preparation of beans is a secular and cultural practice. Cooking is probably the oldest method and is aimed mainly at making them consumable and developing their aroma as it also promotes the inactivation, destruction, or removal of antinutritional or thermolabile factors. Soaking, which consists of leaving the raw beans in water, usually overnight, can be a complementary method in the preparation of beans. The residual soaking water can be discarded or maintained, de- 
pending on cultural or personal preference. Discarding it can aid in the removal of water-soluble components, such as the flatulence causing raffinose-type oligosaccharides, though the amounts of raffinose-type oligosaccharides removed depend on the soaking time, solution, and temperature, and also on the type of bean. When the residual soaking and cooking waters are not discarded, the contents of raffinose-type oligosaccharides can remain after the heat treatment. However, when the residual soaking and cooking waters are discarded, significant amounts of raffinose-type oligosaccharides can be removed from the beans (7). Although this procedure is secular, it is based purely on experience, with no scientific nature, and is thus empirical. However, some factors are known, such as the decrease of cooking time with soaking, and more profound aspects, such as the existence of $\alpha$-galactosidase enzyme (E.C. 3.2.1.22) in the bean (8), which would cause, at least in part, a cleavage of the $\alpha 1-6$ galactosidic linkage of the raffinose-type oligosaccharides; or the action of this enzyme because of the bacteria present in the large intestine (2). Thus the determination of raffinose-type oligosaccharides in beans remain an object of study.

This study aimed at evaluating the effect of soaking on the domestic preparation of the common bean with respect to its chemical composition and to levels of total sugars, reducing and nonreducing sugars, starch, and raffinose-type oligosaccharides, in soaked and nonsoaked common beans, cooked with or without the residual soaking water, and also in the residual soaking water. The nutritive value of the protein of the differently treated common beans was also evaluated with biological assays determining the Food Conversion Efficiency (FCE) and Net Protein Ratio (NPR).

\section{MATERIAL AND METHODS}

Protein sources. The common bean (Phaseolus vulgaris, L.), cv. IAC-Carioca, batch 05/99, was used, provided by the Centre for the Production of Propagated Material of The Campinas Agronomic Institute, SP, Brazil, the control being a commercial casein (M. CASSAB Comércio e Indústria Ltda., SP, Brazil). The beans were soaked at room temperature $\left(25^{\circ} \mathrm{C}\right)$ for $16 \mathrm{~h}$ in a proportion of $3: 1$ (water: beans), then cooked with the same proportion in a domestic pressure cooker for $40 \mathrm{~min}$ after the air exhaustion (continuous water steam flux). The beans were frozen, freeze-dried, and ground to give a dry flour.

Animals and diets. Eight male, recently-weaned (21 days) Wistar rats $(53.4 \pm 5.4 \mathrm{~g})$ were used per treatment in individual growth cages with diet and water ad libitum, the biological assays laboratory being maintained at a temperature and relative humidity of $23 \pm 1^{\circ} \mathrm{C}$ and $50-60 \%$, respectively, and with a light-dark cycle of $12 \mathrm{~h}$. The protocol of the Commission of Ethics in Animal Experimentation of the Biology Institute of State University of Campinas, SP, Brazil, was observed. There were 5 treatments in the biological assay: A. control diet (casein) (CC); B. diet of casein plus the total soluble solids found in the soaking water (CSS) for compar- ative purposes; $C$. diet of beans soaked and cooked with the residual soaking water (BSWW); D. diet of beans soaked and cooked without the residual soaking water (BSNW); E. diet of beans cooked without soaking (BNS); and an isocaloric aproteic diet (AP), for corrective pur-

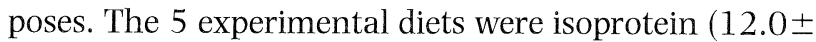
$0.5 \%)$ and isocaloric $(350.9 \pm 37.9 \mathrm{kcal} / 100 \mathrm{~g})$. The diets were formulated according to the diet AIN-93G (9) for growing rats, with the exception of the protein content, to determine the protein quality indexes $(10,11)$.

Chemical characterization of the raw material. The following compositional characteristics were determined in the raw and cooked beans without soaking: crude protein by the semimicro Kjeldahl method (12), using titanium dioxide as a catalyst in the digestion phase (13) and a conversion factor of 5.40 to convert bean nitrogen into protein (14); the conversion factor used for crude protein in the casein standard was 6.38 (15); total lipids (16); crude fiber (17); moisture content (18); ash (19); carbohydrates, determined by difference; total, reducing and nonreducing sugars (20); and starch, in terms of the total saccharifyable substances (21). All analyses were carried out at least in triplicate.

Extraction and HPLC analysis of raffinose-type oligosaccharides. The raffinose-type oligosaccharides were extracted with $80 \%$ ethanol according to the methodology of Vidal-Valverde et al. (22), with adaptations. Portions of $10 \mathrm{~g}$ of the variously prepared bean flours were weighed or $10 \mathrm{~mL}$ of the residual soaking water, and distilled with $100 \mathrm{~mL}$ portions of the $80 \%$ ethanol solution for $15 \mathrm{~min}$ before filtering through a hermex glass funnel with porous plate. The residue was reextracted twice and washed with distilled water until giving a negative Molisch reaction (23). After the volume reached $100 \mathrm{~mL}$, the ethanol was evaporated at $50^{\circ} \mathrm{C}$ in a rotavapor (model RE Büchi), and aliquots of the final extract were filtered through a Millipore membrane (ME $0.45 \mu \mathrm{m} \times 47 \mathrm{~mm}$ ) for the chromatographic analysis. The determinations were carried out in a 9012 Varian HPLC equipment by use of a Star Chromatography Workstation program and refractive index detector (Varian Star 9040 IR). The following chromatographic conditions were used: $\mathrm{NH}_{2}$ column (Merck, 12.5×4 $\mathrm{mm})$, mobile phase of acetonitrile-ultra pure water (18.2 M $\Omega$ ) $75: 25 \mathrm{v} / \mathrm{v}$, flow rate of $1 \mathrm{~mL} / \mathrm{min}$, injection volume of $20 \mu \mathrm{L}$, refractive index detector. Raffinose and stachyose standards (Sigma Chemical Co., St. Louis, Missouri, USA) were used to study the linearity of the response of different concentrations of the raffinose and stachyose oligosaccharides with respect to peak area and to construct calibration curves. A quantification of each oligosaccharide was calculated by a comparison of the peak area with the corresponding standard at least in triplicate, with the exception of the oligosaccharide verbascose, whose standard was not available and was therefore identified by its retention time and quantified by comparison with the areas of the chromatographic peaks of the oligosaccharides raffinose and stachyose $(24,25)$.

Statistical analysis. The results were submitted to 
an analysis of variance (ANOVA) and to the Duncan's means test, using the program STATISTICA $6.0^{\circledR}$ (StatSoft, Inc, USA) and considering $p<0.05$ as the minimum acceptable probability for the difference between the means.

\section{RESULTS AND DISCUSSION}

Chemical characterization of the raw material

The proximate composition of the common bean used can be found in Table 1. The results of this analysis were used as a basis to calculate the experimental diets used in the biological assay.

The contents of total reducing and nonreducing sugars can be found in Table 2 .

An analysis of Table 2 shows that the cooking process alone (BNS) was responsible for a reduction of $22.5 \%$ of the total sugars. However, when we consider the process of soaking before cooking, with the residual soaking water being discarded (BSNW), it can be seen that the reduction reached $80.6 \%$, compared to the levels of total sugars found in the raw bean.

The physical-chemical changes occurring in the beans and the water during soaking are still not well understood. According to Bakr (26), the hydration occurring in the grains can aid the extraction of compo-

Table 1. Proximate composition of the common bean (Phaseolus vulgaris, L.) cv. IAC-Carioca, both raw (RB) and cooked and freeze-dried without soaking (BNS), dry weight basis (mean and standard deviation, $n=6$ )-batch 05/99.

\begin{tabular}{lcc}
\hline Components (\%) & \multicolumn{1}{c}{ RB } & \multicolumn{1}{c}{ BNS } \\
\hline Moisture content & $9.4 \pm 0.1$ & $1.5 \pm 0.1$ \\
Proteins & $16.7 \pm 0.1$ & $19.5 \pm 0.1$ \\
Lipids & $2.1 \pm 0.0$ & $2.5 \pm 0.1$ \\
Ash & $0.5 \pm 0.0$ & $0.6 \pm 0.0$ \\
Fibers & $4.2 \pm 0.1$ & $5.6 \pm 0.2$ \\
Carbohydrates* & 58.5 & 68.2 \\
Total solids & 90.6 & 98.5 \\
\hline
\end{tabular}

* Determined by difference. nents by the soaking water. This hydration would activate enzymes within the bean, resulting in the endogenous degradation of constituents, generating cleavage products that would pass into the soaking water, diffusing low molecular weight products. Thus some sugars, including glucose, fructose, sucrose, raffinose, stachyose, and verbascose, could be present in the residual soaking water. The heat treatment could also contribute to physical-chemical alterations in the common bean, such as changes in the resulting bean structure, which could be demonstrated by the amounts of total reducing and nonreducing sugars found in the cooked soaked and nonsoaked beans, compared to the raw beans.

The contents of starch (total saccharifyable substances) found in the different domestic preparations of the common bean can be seen in Table 3 .

It was shown that the starch content differed between the raw beans and the various domestic preparations of beans, which showed reduced contents. In the BSNW samples, where the soaking water was discarded, there was a reduction of $26.8 \%$ compared to the raw bean. Thus as observed with the amounts of the total reducing and nonreducing sugars found, soaking associated with cooking or otherwise contributed to a reduction in the amounts of total saccharifyable substances in the variously prepared domestic cooked common bean samples, soaked or not, compared to raw beans (27-29).

Determination of raffinose-type oligosaccharides by HPLC

The contents of these substances are shown in Table 4 and the respective chromatograms in Fig. 1. In the preparation of calibration curves with the raffinose and stachyose standards, the following regression coefficients were found: $r^{2}=0.9955$ and 0.9576 , respectively.

It can be observed that, compared to the raw bean, there was a reduction in the contents of the oligosaccharides raffinose $(20.0 \%$ and $25.0 \%)$, stachyose $(8.7 \%$ and $24.8 \%$ ), and verbascose $(33.3 \%$ and $41.7 \%)$ for BNS and BSNW. In BSWW there was also a reduction in stachyose $(11.8 \%)$ and verbascose $(16.7 \%)$, but there was an increase in raffinose $(20.0 \%)$. It was also ob-

Table 2. Total reducing and nonreducing sugars in the variously prepared samples of the common bean (Phaseolus vulgaris, L.) cv. IAC-Carioca, dry weight basis (mean and standard deviation, $n=6$ ) - batch 05/99.

\begin{tabular}{lccc}
\hline Treatment & $\begin{array}{c}\text { Total sugars } \\
(\%)\end{array}$ & $\begin{array}{c}\text { Reducing sugars } \\
(\%)\end{array}$ & $\begin{array}{c}\text { Nonreducing sugars } \\
(\%)\end{array}$ \\
\hline Raw bean & $20.03 \pm 0.07^{\mathrm{a}}$ & $6.05 \pm 0.04^{\mathrm{a}}$ & $13.98 \pm 0.06^{\mathrm{a}}$ \\
BNS $^{*}$ & $15.52 \pm 0.09^{\mathrm{b}}$ & $3.54 \pm 0.02^{\mathrm{b}}$ & $11.98 \pm 0.06^{\mathrm{b}}$ \\
BSNW $^{* *}$ & $3.89 \pm 0.03^{\mathrm{c}}$ & $2.53 \pm 0.05^{\mathrm{c}}$ & $1.36 \pm 0.04^{\mathrm{c}}$ \\
BSWW $^{* * *}$ & $8.85 \pm 0.00^{\mathrm{d}}$ & $3.05 \pm 0.05^{\mathrm{d}}$ & $5.80 \pm 0.03^{\mathrm{d}}$ \\
\hline
\end{tabular}

a,b,c,d Different letters in the same column indicate a statistical difference $(p<0.05)$.

\# Values obtained by difference.

* Freeze-dried beans cooked without soaking.

** Freeze-dried beans soaked and cooked without residual soaking water.

*** Freeze-dried beans soaked and cooked with residual soaking water.

Residual soaking water (values expressed in $\mathrm{g} / 100 \mathrm{~g}$ raw beans, dry weight basis, $0.69 \pm 0.00,0.65 \pm 0.01$, and 0.03 \pm 0.01 , respectively, for total sugars, reducing and nonreducing). 
served that verbascose was the oligosaccharide found in the smallest amounts in the different domestic preparations of the common bean (24). The reduction of raffinose-type oligosaccharides after soaking followed by cooking and the residual soaking water being discarded (BSNW) demonstrated the water solubility of these oligosaccharides. According to Sathe et al. (7), the contents of raffinose-type oligosaccharides can be removed from the beans if the residual soaking water is discarded, since the raffinose-type oligosaccharides are soluble and free, but if the residual soaking water is not discarded, the raffinose-type oligosaccharides may remain and be more easily detected, a fact observed in BSWW with respect to raffinose $(26,27,30)$. On the other hand, the presence of the $\alpha$-galactosidase enzyme (E.C. 3.2.1.22) in the bean (8) could be activated during the soaking and to cleave greater oligosaccharides, such as verbascose and stachyose, leading to the formation of raffinose and thus increasing its content.

Therefore the changes occurring in the levels of sugars, specifically raffinose, stachyose, and verbascose, during soaking and cooking, associated or otherwise, can be attributed to the nature of the resulting struc-

Table 3. Contents of starch in terms of total saccharifyable substances in the variously prepared samples of the common bean (Phaseolus vulgaris, L.) cv. IACCarioca, dry weight basis (mean and standard deviation, $n=6)$ - batch 05/99.

\begin{tabular}{lc}
\hline Treatment & Starch content $(\%)$ \\
\hline Raw bean & $46.76 \pm 0.05^{\mathrm{a}}$ \\
BNS* $^{*}$ & $40.19 \pm 0.00^{\mathrm{b}}$ \\
BSNW $^{* *}$ & $34.21 \pm 0.06^{\mathrm{c}}$ \\
BSWW $^{* * *}$ & $36.91 \pm 0.07^{\mathrm{d}}$ \\
\hline
\end{tabular}

a,b,c,d Different letters in the same column indicate a statistical difference $(p<0.05)$.

* Freeze-dried beans cooked without soaking.

** Freeze-dried beans soaked and cooked without residual soaking water.

*** Freeze-dried beans soaked and cooked with residual soaking water.

Residual soaking water (values expressed in $\mathrm{g} / 100 \mathrm{~g}$ raw beans, dry weight basis, $0.46 \pm 0.00$ ). ture of the beans, to their metabolism, and to the diffusion of components to the soaking water (31).

The mean retention times, in minutes, found in the HPLC determinations for raffinose, stachyose, and verbascose were respectively: $6.9 \pm 0.1,12.9 \pm 0.3$, and $24.0 \pm 0.8$. The relative retention time, in minutes, found for verbascose was approximately 0.29 and 0.54 in relation to raffinose and stachyose, respectively, which agrees with other authors $(24,25)$.

The values found for the experimental diets in the biological assay are shown in Table 5 . The mean loss in weight with the aproteic treatment (AP) was $4.7 \pm$ $1.2 \mathrm{~g}$. It was also observed that the diets CC and CSS did not differ from each other $(p>0.05)$ with respect to weight gain and diet consumption, nor in the indexes showing the FCE and the NPR. But they differed from the other experimental diets where the protein source was the common bean, which presented lower values. Also, no statistical differences were found between the various experimental diets using the common bean as a protein source.

It was shown that the amount of flatulence factors present in the soaking water added to the casein diet did not affect the nutritive value of a high-quality protein such as casein (32).

In the domestic preparation of the common bean, various physical-chemical alterations occurred, including the reduction of inconvenient factors such as the raffinose-type oligosaccharides, which cause flatulence. The effect of soaking and cooking on the contents of raffinose-type oligosaccharides demonstrated that discarding the residual soaking water, this being the water not absorbed by the beans, resulted in a reduction of these oligosaccharides. However, it was shown in the biological assay that the amounts of raffinose-type oligosaccharides present in the various domestic preparations of the common bean and in the residual soaking water did not interfere with the use of this food. The raffinosetype oligosaccharides can cause flatulence in susceptible people, leading to abdominal and social discomfort. On the other hand, recent studies have demonstrated that positive effects can be attributed to these oligosaccharides. They can be used as a carbon and energy source by bifidobacteria, which, because of an antago-

Table 4. The oligosaccharides raffinose, stachyose, and verbascose in the variously prepared samples of the common bean

(Phaseolus vulgaris, L.) cv. IAC-Carioca, dry weight basis (mean and standard deviation, $n=6$ ) —batch 05/99.

\begin{tabular}{lccc}
\hline Treatment & Raffinose $(\%)$ & Stachyose $(\%)$ & Verbascose $(\%)$ \\
\hline Raw bean & $0.40 \pm 0.03^{\mathrm{a}}$ & $3.23 \pm 0.18^{\mathrm{a}}$ & $0.12 \pm 0.01^{\mathrm{a}}$ \\
BNS $^{*}$ & $0.32 \pm 0.04^{\mathrm{b}}$ & $2.95 \pm 0.15^{\mathrm{b}}$ & $0.08 \pm 0.00^{\mathrm{b}}$ \\
BSNW $^{* *}$ & $0.30 \pm 0.02^{\mathrm{b}}$ & $2.43 \pm 0.04^{\mathrm{c}}$ & $0.07 \pm 0.00^{\mathrm{b}}$ \\
BSWW & $0.48 \pm 0.02^{\mathrm{c}}$ & $2.85 \pm 0.07^{\mathrm{b}}$ & $0.10 \pm 0.01^{\mathrm{ab}}$ \\
\hline
\end{tabular}

${ }^{a, b, c}$ Different letters in the same column indicate a statistical difference $(p<0.05)$.

* Freeze-dried beans cooked without soaking.

** Freeze-dried beans soaked and cooked without residual soaking water.

*** Freeze-dried beans soaked and cooked with residual soaking water.

Residual soaking water (values expressed in $\mathrm{g} / 100 \mathrm{~g}$ raw beans, dry weight basis, $0.19 \pm 0.03,0.41 \pm 0.02$, and $0.07 \pm 0.02$, respectively, for raffinose, stachyose, and verbascose). 


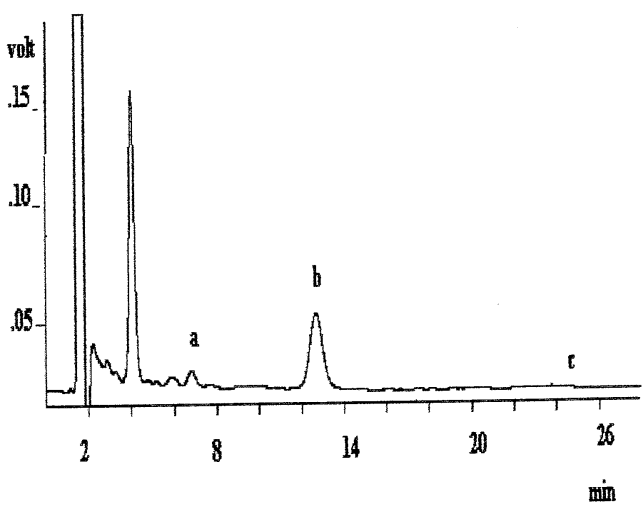

(A)

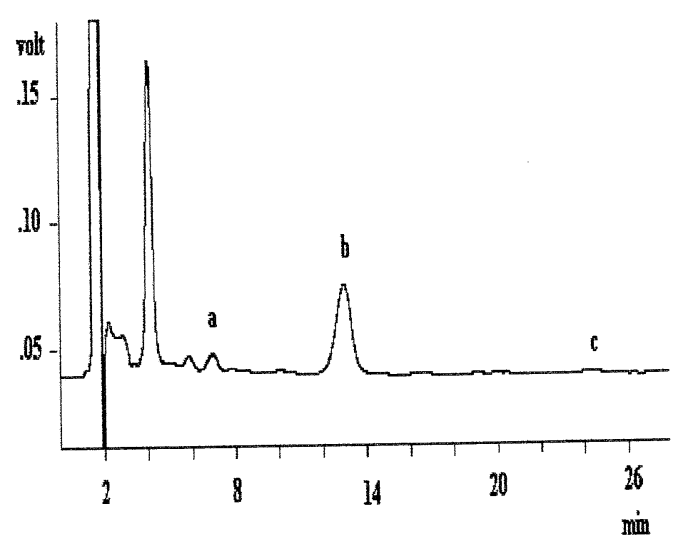

(C)

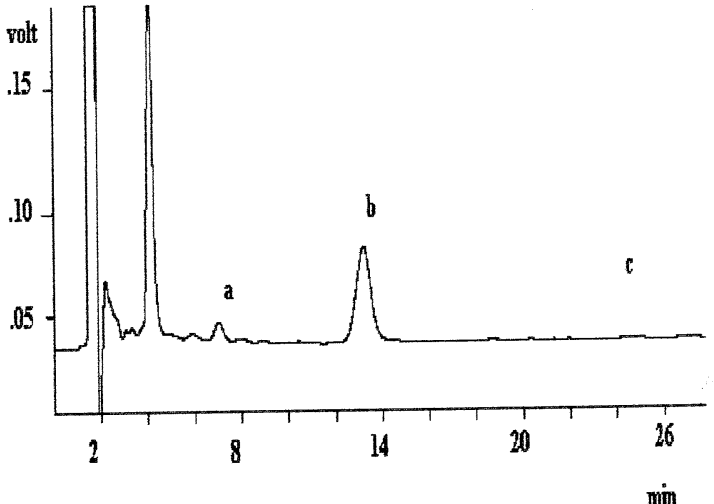

(B)

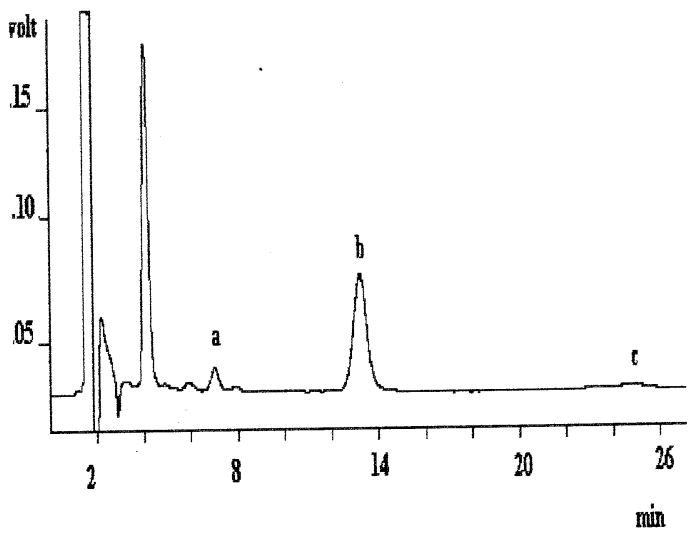

(D)

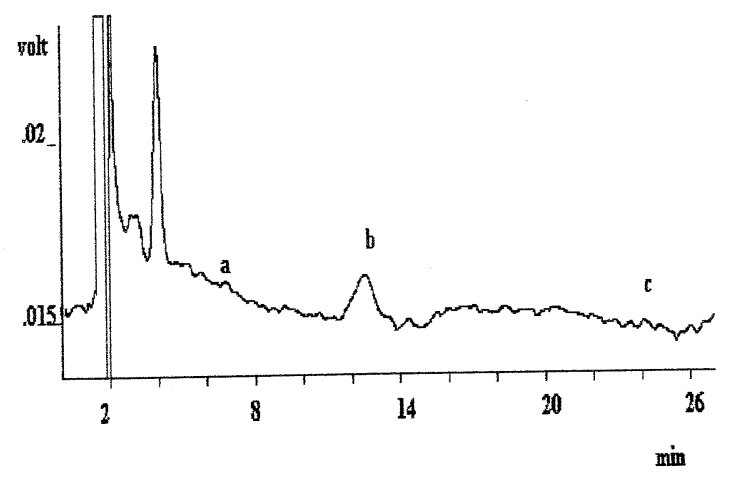

(E)

Fig. 1. Chromatograms of raffinose (a), stachyose (b), and verbascose (c) found in raw beans (A), beans cooked without soaking $(B)$, beans soaked and cooked with the residual soaking water $(C)$, beans soaked and cooked without the residual soaking water, (D) and residual soaking water (E). Column: $\mathrm{NH}_{2} 12.5 \times 4 \mathrm{~mm}$ (Merck); mobile phase: acetonitrile-water (75:25); flow rate: $1 \mathrm{~mL} / \mathrm{min}$; detection: RI.

nic effect, inhibit the activity of colonic putrefactive bacteria, reducing the formation of toxic fermentation products (33). Considering that the raffinose-type oligosaccharides are not really antinutritional factors and can even be beneficial, the use of soaking to reduce these oligosaccharides becomes questionable, since in less susceptible individuals, or in those resistant to flatulence after the ingestion of the common bean, the raffinose-type oligosaccharides can be used as bifidogenic factors. Thus further studies on the effects of soaking in the reduction of flatulence factors are required, plus a future extrapolation to humans who consume complex diets.

In conclusion, it was shown that the use of soaking associated with cooking and discarding of the residual soaking water (BSNW) resulted in a reduction of the flatulence factors raffinose $(25.0 \%)$, stachyose $(24.5 \%)$, and verbascose $(41.7 \%)$, and in a reduction in the contents of total sugars $(80.6 \%)$, reducing sugars $(58.2 \%)$, nonreducing sugars $(90.3 \%)$, and in starch in terms of total saccharifyable substances $(26.8 \%)$. Also, the addition of the flatulence factors present in the residual 
Table 5. Weight gain (g), protein consumption (g), and Food Conversion Efficiency (FCE) and Net Protein Ratio (NPR) of the experimental diets (mean and standard deviation), obtained in the biological assay with 8 male, recently weaned Wistar rats per diet, for 10 days.

\begin{tabular}{lcccc}
\hline Diet & Weight gain $(\mathrm{g})$ & Protein consumption $(\mathrm{g})$ & FCE & NPR \\
\hline CC $^{*}$ & $52.2 \pm 6.2^{\mathrm{a}}$ & $14.1 \pm 1.3^{\mathrm{a}}$ & $0.4 \pm 0.1^{\mathrm{a}}$ & $4.1 \pm 0.4^{\mathrm{a}}$ \\
CSS $^{* *}$ & $48.5 \pm 5.6^{\mathrm{a}}$ & $13.9 \pm 0.6^{\mathrm{a}}$ & $0.4 \pm 0.0^{\mathrm{a}}$ & $3.9 \pm 0.5^{\mathrm{a}}$ \\
BNS $^{* * *}$ & $21.8 \pm 4.0^{\mathrm{b}}$ & $9.1 \pm 1.3^{\mathrm{b}}$ & $0.3 \pm 0.1^{\mathrm{b}}$ & $2.9 \pm 0.4^{\mathrm{b}}$ \\
BSNW $^{\#}$ & $18.8 \pm 3.9^{\mathrm{b}}$ & $7.5 \pm 0.9^{\mathrm{c}}$ & $0.3 \pm 0.1^{\mathrm{b}}$ & $2.9 \pm 0.6^{\mathrm{b}}$ \\
BSWW & $18.2 \pm 4.9^{\mathrm{b}}$ & $7.7 \pm 0.8^{\mathrm{c}}$ & $0.3 \pm 0.0^{\mathrm{b}}$ & $2.8 \pm 0.2^{\mathrm{b}}$ \\
\hline
\end{tabular}

a,b,c Different letters in the same column indicate statistical difference $(p<0.05)$.

* Casein control diet.

** Casein diet plus freeze-dried soluble solids found in the residual soaking water $(0.5 \mathrm{~g} / 100 \mathrm{~g}$ diet $)$.

*** Diet of freeze-dried beans cooked without soaking.

\# Diet of freeze-dried beans soaked and cooked without the residual soaking water.

\#\# Diet of freeze-dried beans soaked and cooked with the residual soaking water.

soaking water to the casein diet did not affect its nutritive value (NPR 3.9 \pm 0.5 ), and the quantities of these substances found in the different domestic preparations of the common bean did not reduce its nutritional value, since they allowed for adequate growth in experimental animals fed on diets containing these legumes.

\section{Acknowledgments}

The authors are grateful to FAPESP (Fundação de Amparo à Pesquisa do Estado de São Paulo) for the financing of this research project (Grant 1998/4325-0) and for the concession of research scholarships to QueIroz KS (Grant 98/0342-7) and to HeLBIG E (Grant 98/04324-7). They also thank Dr. Priscila Fratin de Medina (Campinas Agronomic Institute, SP, Brazil) for donating the pure cultivar of the common bean (Phaseolus vulgaris, L.), Dr. Olavo Rusig from the Company M. CASSAB Comércio \& Indústria Ltda. for providing the vitamin mixture and to Corn Products Ltd., for the donation of dextrinised starch.

\section{REFERENCES}

1) Yokoyama LP. 1999. Aspectos conjunturais da cultura do feijão no período de 1988/89 a 1997/98. In: VI Reunião Nacional de Pesquisa de Feijão. Embrapa Arroz e Feijão 6: 709-712.

2) Jood S, Mehta U, Singh R, Bhat CM. 1985. Effect of processing on flatus-producing factors in legumes. J Agric Food Chem 33: 268-271.

3) Caspary WF. 1992. Physiology and pathophysiology of intestinal absorption. Am J Clin Nutr 55: 299-308.

4) Reddy NR, Pierson MD, Sathe SK, Salunkhe DK. 1984. Chemical, nutritional and physiological aspects of dry bean carbohydrates-a review. Food Chem 13: 25-68.

5) Meredith FI, Thomas CA, Snook ME, Himmelsbach DS, Van-Halbeek H. 1988. Soluble carbohydrates, oligosaccharides and starch in lima bean seeds. J Food Sci 53: 768-771.

6) Sánches-Mata M, Teruel-Peñuela M, Cámara-Hurtado M, Díez-Marqués C, Torija-Isasa ME. 1998. Determination of mono-, di-, and oligosaccharides in legumes by high-performance liquid chromatography using an amino-bonded silica column. J Agric Food Chem 46: 3648-3652.
7) Sathe SK, Despande SS, Salunkhe DK, Rackis JJ. 1984. Dry beans of Phaseolus. A review. Part 2. Chemical composition: carbohydrates, fiber, minerals, vitamins and lipids. Crit Rev Food Sci Nutr 21: 41-93.

8) Baldini VLS, Draetta IS, Park YP. 1985. Purification and characterization of $\alpha$-galactosidase from bean Phaseolus vulgaris. J Food Sci 50: 1766-1777.

9) Reeves PG, Nielsen FH, Fahey GC Jr. 1993. AIN-93 purified diets for laboratory rodents; final report of the American Institute of Nutrition ad hoc writing committee on the reformulation of the AIN-76A rodent diet. $J$ Nutr 123: 1939-1951.

10) Pellet PL, Young VR. 1980. Nutritional Evaluation of Protein Foods. 154 p. The United Nations University, Tokyo.

11) Goena M, Marzo F, Fernández-González L, Tosar A, Frühbeck G, Santidrián S. 1989. Effect of the raw legume Vicia ervilia on muscle and liver protein metabolism in growing rats. Rev Esp Fisiol 45: 55-60.

12) Association of Official Analytical Chemists. 1975. Official Methods of Analysis of A.O.A.C. International. 11th ed (Hortwitz W, ed), p 927-928. A.O.A.C. International, Washington DC.

13) Williams PC. 1973. The use of titanium dioxide as a catalyst for large scale Kjeldahl determination of the total nitrogen content of cereal grains. J Sci Food Agric 24: 343-348.

14) Mossé J. 1990. Nitrogen to protein conversion factor for ten cereals and six legumes or oilseeds. A reappraisal of its definition and determination. Variation according to species and to seeds protein content. J Agric Food Chem 38: $18-24$.

15) Association of Official Analytical Chemists. 1995. Official Methods of Analysis of A.O.A.C. International. 16th ed (Cunniff PA, ed), p 55. A.O.A.C. International, Washington DC.

16) Bligh EG, Dyer WJ. 1959. A rapid method of total lipid extration and purification. Can J Biochem Physiol 37: 911-917.

17) Angelucci E, Carvalho CRL, Carvalho PRN, Figueiredo IB, Mantovani DMB, Moraes RM. 1987. Manual Técnico de Análises de Alimentos, p 52-53. Instituto de Tecnologia de Alimentos, Campinas.

18) Pearson D. 1976. Téecnicas de Laboratório Para el Análisis de Alimentos, p 62-68. Acribia, Zaragoza.

19) Lees R. 1979. Manual de Análisis de Alimentos, p 17, 
124-125. Acribia, Zaragoza.

20) Lara WH. 1976. Normas Analíticas do Instituto Adolfo Lutz. 2nd ed, p 40-44. Edgard Blucher, São Paulo.

21) Bergeret G. 1937. Curso de industrias agricolas: tecnica analitica. Separata da Revista AGROS 7: 98-100.

22) Vidal-Valverde C, Frias J, Valverde S. 1993. Changes in the carbohydrate composition of legumes after soaking and cooking. J Am Diet Assoc 93: 547-550.

23) Assumpção RMV, Morita T. 1968. Manual de Soluções, Reagentes e Solventes: Padronização, Preparação e Purificação, p 328. Edgard Blucher, São Paulo.

24) Revilleza MJR, Mendonza EMT, Raymundo LC. 1990. Oligosaccharides in several Philippine indigenous food legumes: determination, localization and removal. Plant Foods Hum Nutr 40: 83-93.

25) Macrae R, Zand-Moghaddam A. 1978. The determination of the component oligosaccharides of lupinseeds by high pressure liquid chromatography. J Sci Food Agric 29: 1083-1086.

26) Bakr AA. 1996. Effect of Egyptian cooking methods of faba beans on its nutritive value, dietary protein utilization and iron deficiency anemia. 1. The role of main technological pretreatments. Plant Foods Hum Nutr 49: 83-92.

27) Vidal-Valverde C, Frias J, Sotomayor C, Diaz-Pollan C, Fernandez M, Urbano G. 1998. Nutrients and antinu- tritional factors in faba beans as affected by processing. Z Lebensm Unters Forsch 207: 140-145.

28) Nwinuka NM, Abbey BW, Ayalogu EO. 1997. Effect of processing on flatus producing oligosaccharides in cowpea (Vigna unguiculata) and the tropical african yam bean (Sphenostylis stenocarpa). Plant Foods Hum Nutr 51: 209-218.

29) Kataria A, Chauhan BM, Punia D. 1990. Effect of domestic processing and cooking methods on the contents of carbohydrates of amphidiploids (black gram $\times$ mung bean). Food Chem 36: 63-72.

30) Abdel-Gawad AS. 1993. Effect of domestic processing on oligosaccharide content of some dry legume seeds. Food Chem 46: 25-31.

31) Mulyowidarso RK, Fleet GH, Buckle KA. 1991. Changes in the concentration of carbohydrates during the soaking of soybeans for tempe production. Int J Food Sci Technol 26: 595-606.

32) Agunbiade SO, Longe OG. 1999. Essential amino acid composition and biological quality of yam bean, Sphenostylis stenocarpa (Hochst ex A. Rich) harms. Nahrung 43: 22-24.

33) Tomomatsu H. 1997. Ingestion of oligosaccharides increases the bifidobacteria population in the colon, wich in turn contributes to human health in many ways. Food Technol 48: 63-67. 